\title{
The Impact of ICT Investment and Diffusion on Economic Growth: Empirical Evidence from Rwanda
}

${ }^{1}$ MUGABE Roger, ${ }^{2}$ Liu Shulin, ${ }^{3}$ Byringiro Enock

\author{
${ }^{1,2}$ School of Economics, Wuhan University of Technology, Wuhan, China \\ ${ }^{1,3}$ School of Economics and Business studies, Kigali Independent University ULK, \\ Kigali, Rwanda
}

(Email:mugabersshavi@gmail.com, liqor@163.com, enockbyiringiro5@gmail.com)

\begin{abstract}
This study evaluates the influence of Information and Communication Technologies (ICT) investment and diffusion on Rwanda's economic growth. At the level we recommend, ICT imports greatly improve intermediate inputs to capital goods, resulting in increased economic growth. We use the most recent available data on technical innovation and investment for our empirical study, which spans the years 2005Q1 to 2020Q4. The results of regression analysis show that ICT development has little effect on Rwanda's economic growth. However, we notice a patchwork of information on ICT investment. We utilize ICT goods exports and imports as a proxy for ICT investment, based on previous research. Surprisingly, ICT goods exports have had no impact on Rwanda's economic growth. We do notice, however, that a $1 \%$ increase in ICT goods imports boosts economic growth by 3.9 percent. At this level, ICT goods import greatly boost the intermediate input to capital goods, resulting in increased economic growth. As a result, officials should ensure that ICT goods imports should be prioritized through supporting ICT investment to boost economic growth.
\end{abstract}

Keywords: ICT investment, ICT diffusion, Economic growth, Rwanda.

\section{Introduction}

Recent investments have fueled enormous expansions in the telecommunications industry, as well as becoming one of the major drivers of economic growth in several other key sectors. Information and communication technology (ICT) influences modern civilization by facilitating information sharing. Human development is undergoing a paradigm shift as a result of the effects of the ICT revolution, which refers to the process of expanding the range of options available to society, such as education, healthy living, and living standards (Yakunina and Bychkov, 2015).

The importance of technological advancement and innovation in economic development has long been recognized. ICT improves the efficiency of many different economic activities by increasing the availability of information, forming new ways of communication, reformatting production processes, and increasing the availability of 
information. Internet users continue to increase around the world as ICT and telecoms evolve at a rapid pace. "Half of the world's population is predicted to be connected to the internet by the end of 2019 at the latest," according to the Broadband Commission for Sustainable Development (International Telecommunication Union, 2018). As a result, civilizations have achieved a greater connection than ever before in less than two decades (Lee et al., 2017).

The majority of developing countries, including Rwanda, have implemented a variety of reforms to promote the use of ICT in their economy. Rwanda has distinguished itself as a country that has "bet big" on digitization as a means of accelerating growth and reducing poverty, despite its tiny size. ICT is recognized as a cross-cutting enabler for development in the National Strategy of Transformation (NST1). Greater digital adoption and ICT-driven innovation are viewed as critical to boosting productivity in both the primary and secondary sectors (World Bank, 2019). Meanwhile, the use of digital tools and platforms can aid in the growth of services (banking, hospitality), increase access to new markets through e-commerce, and provide a variety of benefits to users, including ways to increase household income creation. Underpinned by strong government institutions and leadership, Rwanda's government has adopted an ambitious digital agenda articulated by a suite of five-year strategies to support the progressive rollout of digital infrastructure, public e-service, increase digital skills, and position Rwanda as a regional ICT hub (Rwanda Economic Update, 2020).

Rwanda's digital development has so far been marked by a significant state investment push in sectors like digital infrastructure and public service delivery. This has enabled Rwanda to achieve some of the continent's highest $3 \mathrm{G}$ and $4 \mathrm{G}$ network coverage rates, giving mobile broadband to almost all Rwandans. Rwanda has emerged as a top African performer in both worldwide 'e-government' and 'doing business' rankings, thanks to the expansion of the government's e-service offering and allowing regulatory reform. Furthermore, the government has formed several innovative collaborations to increase digital literacy and build a support infrastructure for techbased start-ups. The licensed communications service providers' operations in the country have had some noticeable macroeconomic consequences in terms of job creation, faster delivery services, lower transportation costs, increased security, and higher national output (Millicom and the GSMA., 2018). Nonetheless, to sustain the increased digitization of Rwanda's economy, substantial measures will be required in the future.

According to these findings, Rwanda's regulatory authorities should change their policies on ICT spread and development. This data, on the other hand, comes from prior decades, during which the ICT sector prospered admirably. To the best of our knowledge, there is no empirical data on the influence of technological innovation on Rwanda's long-term economic sustainability. This will be the first empirical assessment of the impact of ICT development on economic growth in the country. We believe that imports of ICT goods (as a fraction of total imports) will have a significant impact on economic growth (see Figure 1). 


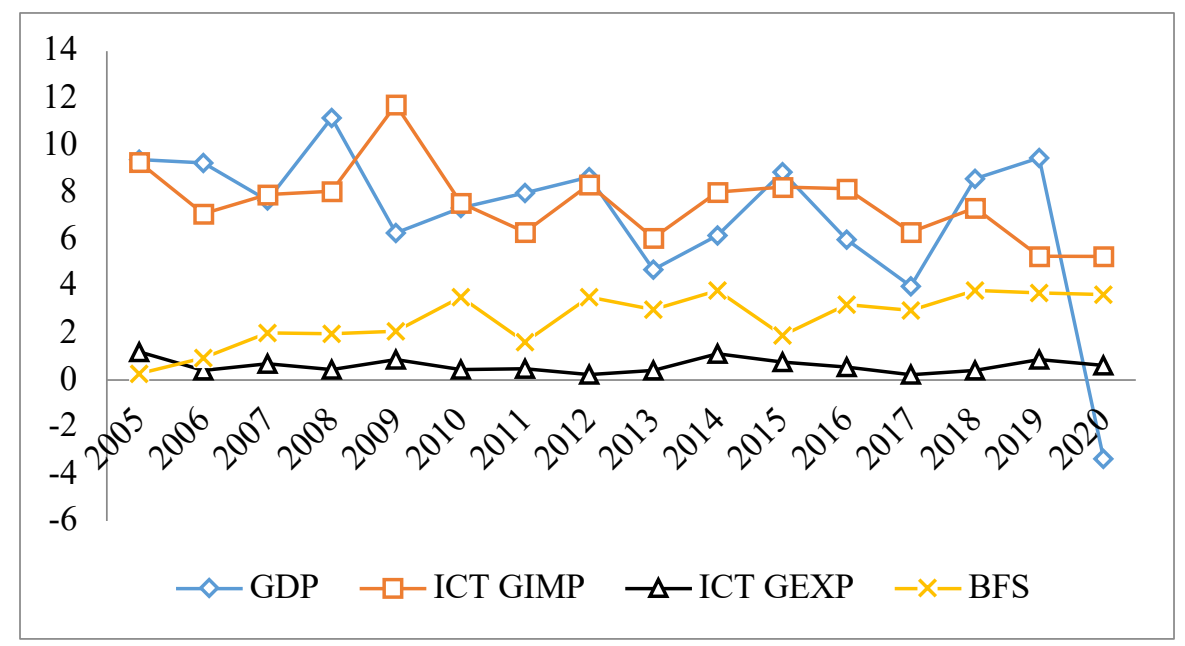

Figure 1. ICT investment and diffusion and economic growth. Note. GDP, ICT GIM, ICTGEXP, and indicate the GDP growth (annual percent), ICT goods imports (percent of total goods imports), ICT goods exports (percent of total goods exports) and fixed broadband subscriptions (per 100 people) respective

There are five primary components to this study. The second section is a review of the relevant literature. The methods utilized in the study are outlined in Section 3. The analysis and interpretation of the data are presented in Section 4. The conclusion is presented in the final section.

\section{Literature Review}

The expansion of information and communication technology (ICT) in the global economy is continuing. ICT has recently played a key role in speeding up globalization and economic progress, as well as making communications and business more worldwide (Maneejuk and Yamaka, 2020). As part of the growth of Industry 4.0, ICT develops new techniques in sustainable industrial manufacturing Stock and Seliger (2016), (Stock and Seliger, 2016), (Stock and Seliger, 2016).

ICT has two main roles: capital deepening as a result of investment and the contribution of all productivity drivers. Businesses have benefited from ICT investment by cutting communication and coordination costs. Investing in information and communication technology can also help to boost efficiency and productivity (Erumban and Das, 2016).

In the empirical research, various techniques of using ICT to boost economic growth have been presented. It can be obtained in two ways: directly through greater productivity and growth in industries that produce ICT goods and services, and indirectly through improved investment quality and productivity in industries that use ICT assets in their production (van et al., 2011). This increased output occurs in a variety of ways. First, information and communication technology (ICT) boosts industrial input demand while cutting transaction costs (Roller and Waverman, 2001). Second, ICT boosts output and efficiency in labor productivity in ICT-using businesses, increasing labor productivity (van et al., 2011). Third, because of its forward and backward connections with the economy, ICT has an impact on productivity. In addition, ICT can boost economic performance by providing market data, 
simplifying information transmission, and boosting competition, entrepreneurial activity, job search processes, and idea diffusion (Czernich et al., 2011). Furthermore, the usage of ICT in the workplace has increased worker productivity, competitive advantage, and efficiency, resulting in higher corporate growth (Evangelista et al., 2014), (Henry and Stephen, 2010).

Both empirical and theoretical studies have proved the impact of telecommunication technology on economic growth. Adedoyin et al. (2020) for the United States; Chakpitak et al. (2018) for Thailand; Kumar et al. (2016) for China; Agarwal et al. (2018) for India; Salahuddin and Gow (2016) for South Africa; Ishida (2015) for Japan; and Salahuddin and Alam (2015) for Australia, among others, have emphasized the importance of ICT in enhancing economic growth.

Several cross-national studies have also confirmed that ICT has a positive impact on economic growth. Khan et al. (2020) for South Asia; Asongu and Odhiambo (2019) for Africa; Alshubiri et al. (2019) for the Gulf Cooperation Council (GCC); Kurniawati (2020) for the OECD; Ghosh (2017) for the Middle East and North Africa; Zhang and Danish (2019) for Asia; and Donou-Adonsou and Lim (2018) for SSA, for example. Furthermore, the findings show that ICT has been shown to be particularly important in boosting economic growth in both developed (Kurniawati, 2020; Myovella et al., 2020; Nair et al., 2020) and developing countries (Kurniawati, 2020; Myovella et al., 2020; Nair et al., 2020) and developing countries (Kurniawati, 2020; Maneejuk and Yamaka, 2020; Solomon and van Klyton, 2020; Zhang and Danish, 2019).

When studying the relationship between ICT and economic growth, other explanatory variables must be included. Capital (Adeleye and Eboagu, 2019; Muhammad and Khan, 2019), labor (Solarin, 2020), foreign direct investment (Adedoyin et al., 2020; Asongu and Odhiambo, 2020), and trade openness (Adedoyin et al., 2020; Asongu and Odhiambo, 2020) are all factors to consider (Ahmed, 2017; Kurniawati, 2017). There is no empirical evidence evaluating the impact of ICT investment and spread on Rwanda's economic growth, according to the extant literature. In order to address a vacuum in the empirical literature, our study focuses on this pending topic.

\section{Research Methodology}

\subsection{Data Source and Variable Descriptions}

The World Development Indicators (WDI) in the World Bank Database were used to collect data for all of the variables. The information was gathered during 16 years (2005-2020). The annual data sets were turned into quarterly data sets from 2005Q1 to 2020Q4 to expand the sample size. Using E-views version 10, the quarterly data were interpolated from the annual time series data. The low frequency to highfrequency approach was used, as well as the quadratic match average and quadratic match sum for each low-frequency series observation.

Economic growth (annual percent), labor (LAB) which represented total labor participation, and capital (CAP) which represented gross fixed capital formation to the GDP was among the variables examined in this study. ICT was broken down into four basic categories. First, two variables are utilized as proxies for ICT investment (ICT goods exports and imports). Users' ICT diffusion is proxied by the next two variables 
(mobile cellular subscriptions and fixed broadband subscriptions). The sum of goods and services exports and imports as a percentage of GDP was referred to as trade openness (TOP). Furthermore, domestic lending to the private sector was used as a proxy for financial development (FD). Finally, the ratio of foreign direct investment net inflows to GDP was represented by foreign direct investment (FDI). In a bid to reduce the data heterogeneity, the variables were converted into their natural logarithm form.

\subsection{Empirical Model Specification}

Following the work of Ishida (2015), we consider the following specification to analyze the impact of ICT investment and diffusion on Rwanda's economic growth (also see Toader et al. 2018).

$$
\text { growth }_{t}=\beta_{0}+\beta_{1} * I C T_{\text {impt }}+\beta_{2} * I C T_{\text {expt }}+\beta_{3} * I U_{t}+\beta_{4} * M C S_{t}+\theta^{*} * X_{t}+\varepsilon_{t}
$$

Where the dependent variable, growth, is the real GDP, measured by gross domestic product growth (annual percent), and the explanatory variables include the constant $\left(\beta_{0}\right)$, the ICT goods imports $\left(I C T_{i m p}\right)$, ICT goods exports $\left(I C T_{\text {exp }}\right)$, internet users (IU), mobile cellular subscriptions (MCS), and a vector of the control variables $\left(X_{t}\right)$, which includes labor (LAB), capital (CAP), Trade openness (TOP), and, foreign direct investment (FDI), $\varepsilon_{t}$ is the error term and " $t$ " is the time series index. Equation (1) is the basis of estimating the relationship between economic growth and ICT investment and diffusion. Substituting the set of conditioning variables will give:

$$
\begin{aligned}
\text { growth }_{t}=\beta_{0}+\beta_{1} * I C T_{\text {impt }}+ & \beta_{2} * I C T_{\text {expt }}+\beta_{3} * I U_{t}+\beta_{4} * M C S_{t}+\beta_{5} * L A B_{t}+\beta_{6} * C A P_{t}+ \\
& \beta_{7} * T O P_{t}++\beta_{8} * F D I_{t}+\varepsilon_{t}
\end{aligned}
$$

\section{Data Analysis And Interpretation}

In actual fact, before computing the specified growth equation, the summary statistics are presented in the first instance to give a fair description of the link between economic growth and ICT investment and diffusion for the data set collected for Rwanda over the period 2005Q1-2020Q4. The summary statistics for the entire sample are presented in table 4.1 including minimum, maximum, mean, standard deviation, skewness, kurtosis, and Jarque-Bera value. The descriptive analysis results reveal that ICT imports $(\mathrm{M}=$ 7.56; $\mathrm{SD}=1.31)$ are almost thirteen times greater than the ICT exports $(\mathrm{M}=0.59 ; \mathrm{SD}=$ $0.22)$.

Table 1 Descriptive statistics

\begin{tabular}{|c|c|c|c|c|c|}
\hline Variables & Mean & Maximum & Minimum & Std. Dev & Observations \\
\hline growth $_{t}$ & 7.193406 & 11.16124 & -3.355472 & 2.362625 & 64 \\
\hline$I C T_{\text {impt }}$ & 7.562195 & 11.71726 & 5.261679 & 1.315171 & 64 \\
\hline$I C T_{\text {expt }}$ & 0.595983 & 1.203760 & 0.224654 & 0.225109 & 64 \\
\hline$I U_{t}$ & 0.8142074 & 27.45030 & 11.20000 & 0.712900 & 64 \\
\hline$M C S_{t}$ & 56.03672 & 106.14408 & 22.2978 .0 & 3.550830 & 64 \\
\hline$L A B_{t}$ & 84.76806 & 85.79000 & 84.00667 & 0.547562 & 64 \\
\hline$C A P_{t}$ & 21.64125 & 27.15323 & 14.68254 & 3.438459 & 64 \\
\hline$T O P_{t}$ & 43.63301 & 57.93135 & 33.23977 & 7.821998 & 64 \\
\hline$F D I_{t}$ & 2.657505 & 3.810029 & 0.271467 & 0.928321 & 64 \\
\hline & & & & & \\
\hline
\end{tabular}


Similarly, the fixed broadband subscription (internet users) per 100 persons $(\mathrm{M}=$ $0.81 ; \mathrm{SD}=0.71)$ is substantially greater than the mobile cellular subscription $(\mathrm{M}=$ 56.03; $\mathrm{SD}=3.55$ ). Furthermore, in all situations, Jarque-Bera probability values are smaller than the level of significance. As a result, there isn't enough evidence to rule out the null hypothesis, which states that the data are normally distributed.

A correlation matrix was created to measure the degree of correlation among the variables under examination in order to uncover the problem of multicollinearity in the model. Correlation illustrates how changes in one variable are caused by changes in another. Multicollinearity can occur when there is a significant correlation between variables, particularly the set of explanatory variables. The result of the pair wise correlation matrix is shown in table 2.

If multicollinearity between two independent variables is $70 \%$ or above, it is a cause for concern, according to the rule of thumb. However, there is no significant case of multicollinearity between the set of independent variables in the current study, since the maximum correlation value is 64.0 percent between capital (CAP) and mobile cellular subscriptions (MCS). This demonstrates that the variables in the model are not multicollinear.

Table 2 Pair-wise correlation matrix

\begin{tabular}{|c|c|c|c|c|c|c|c|c|c|}
\hline & 1 & 2 & 3 & 4 & 5 & 6 & 7 & 8 & 9 \\
\hline 1. growth $_{t}$ & 1.00 & & & & & & & & \\
\hline 2. ICT $_{\text {impt }}$ & 0.48 & 1.00 & & & & & & & \\
\hline 3. ICT $_{\text {expt }}$ & 0.53 & 0.57 & 1.00 & & & & & & \\
\hline 4. $U_{t}$ & 0.63 & -0.38 & 0.25 & 1.00 & & & & & \\
\hline 5. MCS & 0.56 & 0.24 & 0.50 & 0.56 & 1.00 & & & & \\
\hline 6. $L A B_{t}$ & 0.41 & -0.64 & 0.23 & 0.43 & 0.48 & 1.00 & & & \\
\hline 7. $C A P_{t}$ & 0.56 & -0.02 & 0.56 & 0.57 & 0.64 & 0.49 & 1.00 & & \\
\hline 8. $T O P_{t}$ & -0.49 & -0.58 & -0.59 & -0.62 & -0.37 & -0.59 & -0.18 & 1.00 & \\
\hline 9. $F D I_{t}$ & 0.25 & 0.49 & 0.43 & -0.37 & 0.24 & 0.5 & 0.32 & 0.18 & 1.00 \\
\hline
\end{tabular}

Table 2 reports the correlation matrix results. The results indicated that Internet users, the ICT goods imports, ICT goods exports, internet users and mobile cellular subscriptions are positively and significantly correlated with economic growth in Rwanda. Besides, capital, labor, and foreign direct investment have a positive correlation with economic growth while trade openness is negatively correlated with economic growth in the country.

\subsection{Unit Root Test Results}

To avoid the problem of trended data in time series data computation, it is but fitting to first and foremost perform the unit root test. The Augmented Dickey-Fuller (ADF) test and the Phillips-Perron (PP) tests are used to determine the order of integration of data compiled for each series under consideration. The results of the unit root tests on the variables in levels are presented in tables 3 below.

Table 3 Stationary Test Results using ADF and PP test

\begin{tabular}{|c|c|c|c|c|c|}
\hline \multicolumn{7}{|c|}{ Augmented Dickey-Fuller (ADF) test } \\
\hline Variables & Level/Alevel & $\begin{array}{l}\text { ADF } \\
\text { Statistic }\end{array}$ & $\begin{array}{l}\text { ADF Critical } \\
\mathbf{( 5 \% )}\end{array}$ & P-Value & Inference \\
\hline growth & Level & -2.577025 & -3.440681 & 0.2915 & $\mathrm{I}(1)$ \\
\hline
\end{tabular}


The Impact of ICT Investment and Diffusion on Economic Growth: Empirical Evidence from Rwanda

\begin{tabular}{|c|c|c|c|c|c|}
\hline & $\Delta$ level & -4.682401 & -3.440681 & 0.0011 & \\
\hline \multirow[t]{2}{*}{$I C T_{\text {impt }}$} & Level & -2.114880 & -2.881123 & 0.2392 & \multirow[t]{2}{*}{$\mathrm{I}(1)$} \\
\hline & $\Delta$ level & -8.433439 & -3.440681 & 0.0000 & \\
\hline \multirow{2}{*}{$I C T_{\text {expt }}$} & Level & -2.464762 & -3.440681 & 0.3452 & \multirow[t]{2}{*}{$\mathrm{I}(1)$} \\
\hline & $\Delta$ level & -11.99741 & -3.440894 & 0.0000 & \\
\hline \multirow[t]{2}{*}{$I U$} & Level & -2.785352 & -3.440681 & 0.2051 & \multirow[t]{2}{*}{$\mathrm{I}(1)$} \\
\hline & $\Delta$ level & -3.501550 & -3.440681 & 0.0429 & \\
\hline \multirow[t]{2}{*}{$M C S$} & Level & -3.181252 & -3.441552 & 0.0924 & \multirow[t]{2}{*}{$\mathrm{I}(1)$} \\
\hline & $\Delta$ level & -3.811734 & -3.441552 & 0.0186 & \\
\hline \multirow[t]{2}{*}{$L A B$} & Level & 0.159736 & -2.881123 & 0.9691 & \multirow[t]{2}{*}{$\mathrm{I}(1)$} \\
\hline & $\Delta$ level & -3.468589 & -3.440681 & 0.0466 & \\
\hline \multirow[t]{2}{*}{$C A P$} & Level & -1.442709 & -3.440681 & 0.8443 & \multirow[t]{2}{*}{$\mathrm{I}(1)$} \\
\hline & $\Delta$ level & -2.357207 & -1.943012 & 0.0183 & \\
\hline \multirow[t]{2}{*}{ TOP } & Level & -1.185795 & -3.440681 & 0.9092 & \multirow[t]{2}{*}{$\mathrm{I}(1)$} \\
\hline & $\Delta$ level & -4.894552 & -3.440681 & 0.0005 & \\
\hline \multirow[t]{2}{*}{$F D I$} & Level & -1.699085 & -3.440471 & 0.7470 & \multirow[t]{2}{*}{$\mathrm{I}(1)$} \\
\hline & $\Delta$ level & -4.832045 & -3.440471 & 0.0006 & \\
\hline
\end{tabular}

\subsection{Co-integration Analysis}

Given that the model's variables are integrated in the same order I(1) at the first difference, a cointegration test would be the next step in this empirical research to determine the variables' long-term relationship. The approach of cointegration proposed by Johansen and Juselius (1990) states that the variables entering the cointegration relationship must be integrated in the same order. The trace test (trace) and the maximum eigen value test $(\max )$ are two statistical tests suggested by Johansen and Juselius $(1988,1990)$. Tables 4 and 5 show the results of these two experiments.

Table 4Unrestricted Co-integration Rank Test (Trace)

\begin{tabular}{|c|c|c|c|c|}
\hline $\begin{array}{c}\text { Hypothesized } \\
\text { No. of CE(s) }\end{array}$ & Eigenvalue & $\begin{array}{c}\text { Trace } \\
\text { Statistic }\end{array}$ & $\begin{array}{c}0.05 \\
\text { Critical Value }\end{array}$ & Prob.** \\
\hline None * & 0.750000 & 417.7882 & 197.3709 & 0.0000 \\
\hline At most ${ }^{*}$ & 0.750000 & 337.3831 & 159.5297 & 0.0000 \\
\hline At most $*^{*}$ & 0.750000 & 256.9780 & 125.6154 & 0.0000 \\
\hline At most 3 & 0.623587 & 176.5729 & 95.75366 & 0.0000 \\
\hline At most 4 & 0.546355 & 119.9030 & 69.81889 & 0.0000 \\
\hline At most 5 & 0.388311 & 74.05738 & 47.85613 & 0.0000 \\
\hline At most 6 & 0.364355 & 45.54856 & 29.79707 & 0.0004 \\
\hline At most 7 & 0.243919 & 19.26791 & 15.49471 & 0.0128 \\
\hline At most 8 & 0.051239 & 3.050729 & 3.841466 & 0.0807 \\
\hline
\end{tabular}

Table 5 Unrestricted Co-integration Rank Test Result (Maximum Eigenvalue)

\begin{tabular}{|c|c|c|c|c|}
\hline $\begin{array}{c}\text { Hypothesized } \\
\text { No. of CE(s) }\end{array}$ & Eigenvalue & $\begin{array}{c}\text { Max-Eigen } \\
\text { Statistic }\end{array}$ & $\begin{array}{c}0.05 \\
\text { Critical Value }\end{array}$ & Prob.** \\
\hline None & 0.750000 & 80.40507 & 58.43354 & 0.0001 \\
\hline At most $1 *$ & 0.750000 & 80.40507 & 52.36261 & 0.0000 \\
\hline At most $2 *$ & 0.750000 & 80.40507 & 46.23142 & 0.0000 \\
\hline At most $3 *$ & 0.623587 & 56.66998 & 40.07757 & 0.0003 \\
\hline
\end{tabular}


The Impact of ICT Investment and Diffusion on Economic Growth: Empirical Evidence from Rwanda

\begin{tabular}{|c|l|l|l|l|}
\hline At most 4* & 0.546355 & 45.84558 & 33.87687 & 0.0012 \\
\hline At most 5* & 0.388311 & 28.50882 & 27.58434 & 0.0380 \\
\hline At most 6* & 0.364355 & 26.28064 & 21.13162 & 0.0086 \\
\hline At most 7 * & 0.243919 & 16.21718 & 14.26460 & 0.0243 \\
\hline At most 8 & 0.051239 & 3.050729 & 3.841466 & 0.0807 \\
\hline
\end{tabular}

The values of both the trace statistics and the Max-Eigen statistics are greater than their critical values at 5\% significant levels and their corresponding probability values are less than 5\%, which implies that we fail to reject the null hypothesis of no cointegrating relationship at the 5\% significant level. This result confirms that there is a long-run relationship among economic growth, ICT goods imports, ICT goods exports, internet users (IU), mobile cellular subscriptions (MCS) labor (LAB), capital (CAP), Trade openness (TOP), and foreign direct investment (FDI). Since variables can either have long-run or short-run effects, then an error correction model (ECM) is used to disaggregate this effect. The long-run cointegrating relationship is thus specified in table 6 below.

Table 6 Result of the long-run Growth model

\begin{tabular}{|l|l|l|l|l|l|l|c|c|}
\hline growth & $I C T_{\text {impt }}$ & $I C T_{\text {expt }}$ & $I U$ & $M C S$ & $L A B$ & $C A P$ & $T O P$ & $F D I$ \\
\hline & 0.778 & 0.248 & 0.303 & 0.954 & 3.694 & 0.808 & -0.512 & 0.954 \\
\hline & $(0.115)$ & $(0.009)$ & $(0.105)$ & $(0.256)$ & $(0.739)$ & $(0.384)$ & $(0.262)$ & $(0.256)$ \\
\hline
\end{tabular}

The result in table 6 above shows that ICT goods imports, ICT goods exports, internet users (IU), mobile cellular subscriptions (MCS) labor (LAB), capital (CAP), and foreign direct investment (FDI) have a positive effect on GDP growth. These variables are statistically significant in influencing growth, while Trade openness (TOP) was found to have a negative relationship on GDP growth with statistically significant values.

\subsection{Result of the Error Correction Model}

The presence of a long-run relationship among the I(1) variables suggests that the shortrun dynamic model should be estimated. For stationary types of GDP growth, the shortrun error-correction model (ECM) is an autoregressive model, ICT goods imports, ICT goods exports, internet users (IU), mobile cellular subscriptions (MCS) labor (LAB), capital (CAP), trade openness and foreign direct investment (FDI). OLS is used to calculate it. To analyze the short- and long-run behavior of GDP growth in respect to the ICT indicators and the rest of the explanatory variables, the error correction procedure is used. This equation comprises the model's short-run adjustment mechanism. The existence of a unique cointegrating relationship between GDP growth and the collection of explanatory factors was demonstrated in the preceding section. However, there may be disequilibria in the short run, thus the error correction model is used to eliminate divergence from the long-run equilibrium.

Table 7 shows the findings of the short-run dynamic model. The speed of adjustment in removing departure from the long-run equilibrium is indicated by the coefficient of the error correction term. The coefficient is statistically significant at the $5 \%$ level and has the predicted negative sign (-0.822830). The coefficient's significance further shows the presence of a long-run link between GDP growth and the I(1) 
variables in question. The value of the coefficient means that in the current year, almost 82.28 percent of the disequilibrium from the previous year's shock returns to long-term equilibrium.

Table 7 Short-Run Dynamics (ECM), Dependent Variable: $\Delta \operatorname{lnGDP}$

\begin{tabular}{|c|l|l|l|l|}
\hline Variable & \multicolumn{1}{|c|}{ Coefficient } & \multicolumn{1}{|c|}{ Std. Error } & \multicolumn{1}{c|}{ t-Statistic } & \multicolumn{1}{c|}{ Prob. } \\
\hline $\mathrm{C}$ & 0.119738 & 0.357067 & 0.335338 & 0.7460 \\
\hline$\Delta \ln I C T_{\text {impt }}$ & 0.039200 & 0.014572 & 2.690173 & $0.0360^{* *}$ \\
\hline$\Delta I C T_{\text {expt }}$ & -2.224718 & 3.923546 & -0.567017 & 0.5863 \\
\hline$\Delta \ln I U$ & 0.001526 & 0.001637 & 0.932489 & 0.3622 \\
\hline$\Delta \ln M C S$ & -0.146102 & 0.160433 & -0.910676 & 0.3733 \\
\hline$\Delta \ln L A B$ & 0.225858 & 0.074875 & 3.016446 & $0.0053^{*}$ \\
\hline$\Delta \ln C A P$ & 0.506211 & 0.203131 & 2.492038 & $0.0299^{* *}$ \\
\hline$\Delta \ln T O P$ & -0.359798 & 0.195400 & -1.841340 & $0.0821^{* * *}$ \\
\hline$\Delta \ln F D I$ & 0.032353 & 0.011666 & 2.773228 & $0.0117^{* *}$ \\
\hline$\Delta \ln G D P_{(-1)}$ & 0.286718 & 0.095367 & 3.006468 & $0.0070^{*}$ \\
\hline$\Delta \ln I C T_{\text {impt }(-1)}$ & 0.352112 & 0.176747 & 1.992183 & $0.0595^{* * *}$ \\
\hline$\Delta \ln I C T_{\text {expt }(-1)}$ & -1.865908 & 4.998873 & -0.373266 & 0.7120 \\
\hline$\Delta \ln I U_{(-1)}$ & 0.024538 & 0.051676 & 0.474836 & 0.6400 \\
\hline$\Delta \ln M C S_{(-1)}$ & 0.703419 & 0.137058 & 5.132278 & $0.0001^{*}$ \\
\hline$d \ln L A B_{(-1)}$ & 0.667186 & 1.553625 & 0.429438 & 0.6730 \\
\hline$\Delta \ln C A P_{(-1)}$ & 0.852227 & 0.235661 & 3.616321 & $0.0021^{*}$ \\
\hline$\Delta \ln T O P_{(-1)}$ & -0.354647 & 0.159850 & -2.218624 & $0.0683^{* * *}$ \\
\hline$\Delta \ln F D I_{(-1)}$ & 0.204346 & 0.062197 & 3.285467 & 0.0037 \\
\hline $\mathrm{ECM}(-1)$ & -0.822830 & 0.212583 & -3.870638 & $0.0008^{*}$ \\
\hline
\end{tabular}

Note: $(*) ;(* *)$ and $(* * *)$ denote $1 \% ; 5 \%$ and $10 \%$ significance level respectively. R-squared $=0.864970$; Adjusted R-squared $=0.711790 \quad$ DW: 2.082407 ; Prob. $($ F-statistic $)=0.002375$

The estimated solutions of Equation 1 are shown in Table 7 . These findings suggest that ICT export has no effect on Rwanda's economic growth $(\beta=-2.2247, P>$ $0.05)$. These findings are in line with one body of literature, which we label the third body of literature (See Erumban, and Das, 2016; Zhang and Danish, 2019). One plausible explanation is that technological advancements and inventions evict unskilled and low-wage workers from the market, which is the primary cause of increased income inequality in any economy (See Freeman and Soete 1997). [For more information on similar outcomes, see (Ceccobelli et al. 2012) and Ishida (2015)].

However, we find that import-led ICT investment has a statistically significant impact on Rwanda's economic growth $(\beta=0.0392 ; P<0.05)$. According to these log-log model results, a $1 \%$ increase in ICT goods imports boosts Rwanda's economic growth by 3.9 percent, ceteris paribus.

When the Rwandan National Strategy of Transformation (NST1) identifies ICT as a cross-cutting enabler for development, the growth of telecommunications over the previous two decades is striking. Greater digital adoption and ICT-driven innovations are viewed as critical to boosting productivity gains in both the primary and nonprimary sectors (World Bank, 2019), and ICT imports are likely to be a key component 
of intermediate inputs. As a result, information and communication technologies improve the capital goods' intermediate inputs (Colecchia and Schreyer 2002).

Another explanation could be that by using electronic commerce, electronic business, and online financial transactions, the intermediate inputs could lower overall transaction costs in the industry (see Zhang and Danish, 2019). Furthermore, various indirect routes mentioned in the literature, such as (1) promoting trading activities; (2) enhancing the level of education; (3) improving the general public's overall health; (4) promoting the production level; and (5) strengthening social services, can have an indirect impact (See Nair et al., 2020; Myovella et al., 2020; Nair et al., 2020). As a result, ICT imports contribute to Rwanda's total economic growth.

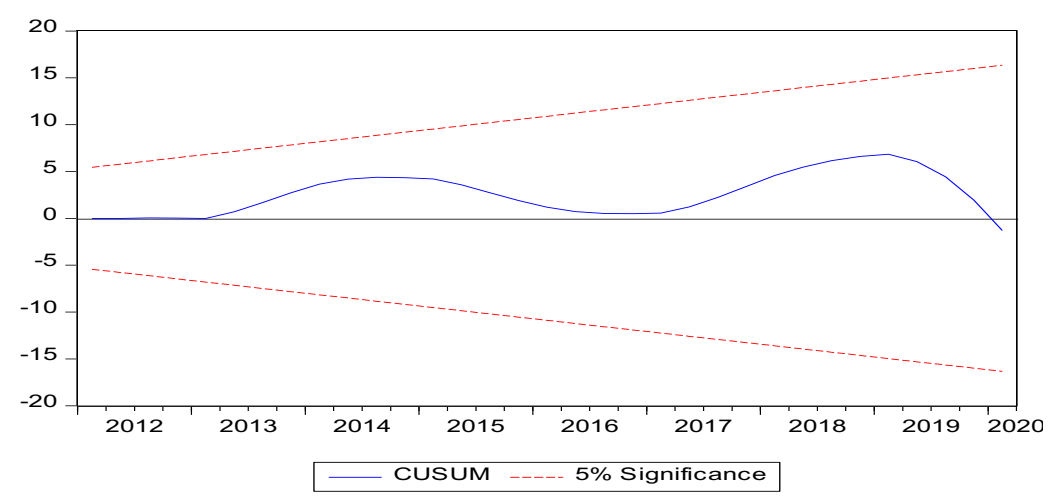

Figure 2. CUSUM Test-Recursive Estimation.

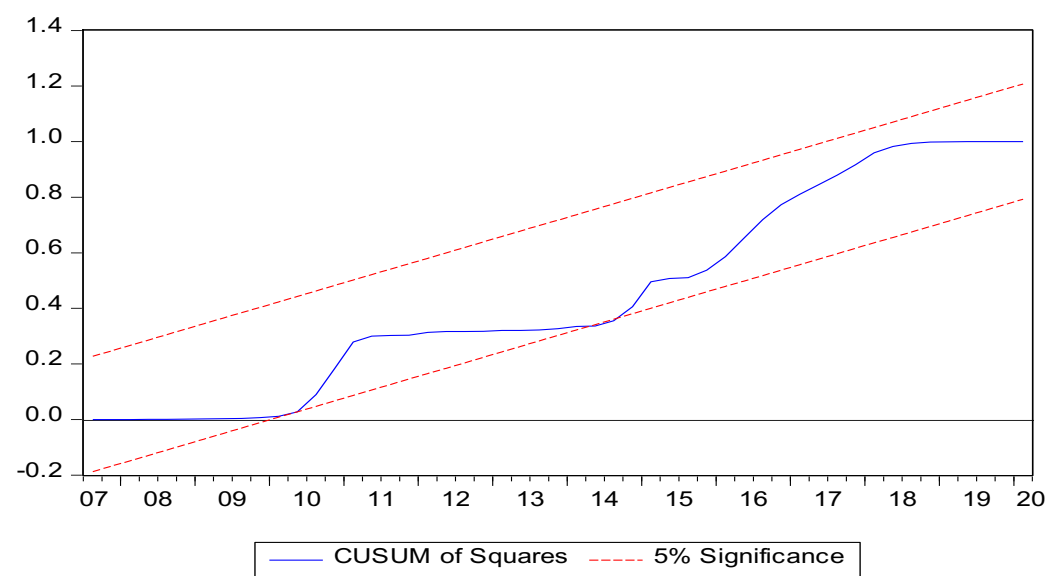

Figure 3. CUSUM of Squares Test-Recursive Estimation.

The CUSUM and CUSUM of squares tests demonstrate the model's stability in the stability analysis (see Figures 2 and 3). Both graphs show that our model is stable at a $5 \%$ level, indicating that the parameters are quite stable.

Table 8 Diagnostic Test

\begin{tabular}{|l|l|l|l|c|}
\hline Test Type & Null Hypothesis & Statistic & Probability & Inference \\
\hline Normality Test & Errors are normally & Jarque-Bera & Probability & Fail to reject \\
(Jarque-Bera Statistics) & distributed & Statistics= & $=0.874676$ & $\mathrm{H}_{0}$ \\
& & 0.267803 & & \\
\hline Serial Correlation & No serially correlated & F-statistics & Prob. Chi- & Fail to reject \\
(Breush-Godfrey Serial & & $=1.383113$ & Squarer = & \\
\hline
\end{tabular}


The Impact of ICT Investment and Diffusion on Economic Growth: Empirical Evidence from Rwanda

\begin{tabular}{|c|c|c|c|c|}
\hline Correlation LM Test) & errors & & 0.1914 & $\mathrm{H}_{\mathrm{o}}$ \\
\hline $\begin{array}{l}\text { ARCH Test } \\
\text { (Autoregressive } \\
\text { Heteroskedasticity Test) }\end{array}$ & $\begin{array}{l}\text { ARCH effect does } \\
\text { not characterize } \\
\text { model's errors }\end{array}$ & $\begin{array}{l}\text { F-statistics } \\
=1.980557\end{array}$ & $\begin{array}{lr}\text { Prob. } & \text { Chi- } \\
\text { Square } & = \\
0.1592 & \end{array}$ & $\begin{array}{c}\text { Fail to reject } \\
\mathrm{H}_{\mathrm{o}}\end{array}$ \\
\hline $\begin{array}{l}\text { Heteroskedasticity Test } \\
\text { (Breush-Pagan- } \\
\text { Godfrey) }\end{array}$ & Homoskedasticity & $\begin{array}{l}\text { F-statistics } \\
=0.298929\end{array}$ & $\begin{array}{lr}\text { Prob. } & \text { Chi- } \\
\text { Square } & = \\
0.8839 & \\
\end{array}$ & $\begin{array}{c}\text { Fail to reject } \\
\mathrm{H}_{\mathrm{o}}\end{array}$ \\
\hline $\begin{array}{l}\text { Model Specification } \\
\text { Test } \\
\text { (Ramsey } \\
\end{array}$ & $\begin{array}{l}\text { Model is correctly } \\
\text { specified }\end{array}$ & $\begin{array}{l}\text { F-statistics } \\
=2.211028\end{array}$ & $\begin{array}{l}\text { Probability } \\
=0.3769\end{array}$ & $\begin{array}{c}\text { Fail to reject } \\
\mathrm{H}_{\mathrm{o}}\end{array}$ \\
\hline
\end{tabular}

The diagnostic test indicates that the model is well-fitting. From probability values greater than $5 \%$, the model is free of difficulties such as non-normality of errors, serially correlated errors, ARCH effect, heteroskedasticity, and functional form misspecification.

Overall, the findings show that ICT dispersion has no substantial impact on Rwanda's economic growth. Rwanda's economic growth is statistically significant as a result of ICT investment. However, we note that only ICT imports contribute to Rwanda's economic growth. When it comes to the second component of ICT investment, ICT exports have a negligible negative impact on economic growth $(\beta=-$ $2.22 ; p>0.05$ ), which is a bad indicator for a country's economy. One likely reason for this is because Rwanda's ICT sector is still in its early stages of development, and ICT exports are failing to reach international standards. To meet the demands of the worldwide market, officials should establish some quality standards for ICT exports.

\section{Conclusion And Recommendations}

The influence of ICT investment and spread on Rwanda's economic growth is the subject of the first half of this study. Second, this study determines the precise amount of ICT goods imports that affect the intermediate input in the manufacturing process. ICT spread had little impact on Rwanda's economic success, according to a regression analysis of data from 2005Q1 to 2020Q4. When we looked at ICT investment as indicated by ICT goods exports and imports, we found mixed outcomes. Surprisingly, Rwanda's economic growth has been unaffected by ICT goods exports. However, we discovered that a $1 \%$ increase in ICT goods imports improves GDP by 3.9 percent, indicating that the economy is entering a new phase. These findings suggest that imports of ICT goods improve the quality of intermediate inputs to capital goods, resulting in higher economic growth. Based on the findings of this empirical study, we believe that governments should prioritize ICT infrastructure development by supporting ICT investment in order to improve economic growth. Imports of ICT items should be larger (as a percentage of total imports) than what we recommend. However, due to data limitations, these findings should be used with caution. Policymakers and the ICT industry are performing well based on these data, as ICT goods imports (as a percentage of total imports) are currently higher. 


\section{References}

1. Adedoyin, F.F., Bekun, F.V., Driha, O.M. and Balsalobre-Lorente, D. (2020), "The effects of air transportation, energy, ICT and FDI on economic growth in the industry 4.0 era: evidence from the USA", Technological Forecasting and Social Change, Vol. 160, 120297. Crossref

2. Adeleye, N. and Eboagu, C. (2019), "Evaluation of ICT development and economic growth in Africa", Netnomics: Economic Research and Electronic Networking, Vol. 20 No. 1, pp. 31-53. Crossref

3. Agarwal, S., Sharma, G., Jhingran, V., Sharma, V. and Rawat, Y. (2018), "Role of ICT in the economic growth of India", Disruptive Technologies Transforming Businesses, Kanpur.

4. Ahmed, E. (2017), "ICT and human capital spillover effects in achieving sustainable East Asian knowledge-based economies", Journal of the Knowledge Economy, Vol. 8 No. 3, pp. 1086-1112. Crossref

5. Alshubiri, F., Jamil, S.A. and Elheddad, M. (2019), "The impact of ICT on financial development: empirical evidence from the Gulf Cooperation Council countries", International Journal of Engineering Business Management, SAGE Publications STM, Vol. 11, 1847979019870670.

6. Asongu, S.A. and Odhiambo, N.M. (2019), "How enhancing information and communication technology has affected inequality in Africa for sustainable development: an empirical investigation", Sustainable Development, John Wiley \& Sons, Vol. 27 No. 4, pp. 647-656.

7. Ceccobelli, Matteo, Simone Gitto, and Paolo Mancuso (2012). ICT capital and labor productivity growth: A non-parametric analysis of 14 OECD countries.

Telecommunications Policy 36: 282-92. Crossref

8. Chakpitak, N., Maneejuk, P., Chanaim, S. and Sriboonchitta, S. (2018), "Thailand in the era of the digital economy: how does digital technology promote economic growth? BT - predictive econometrics and big data", in Kreinovich, V., Sriboonchitta, S. and Chakpitak, N. (Eds), Springer International Publishing, Cham, pp. 350-362.

9. Colecchia, Alessandra, and Paul Schreyer. (2002). ICT investment and economic growth in the 1990s: Is the United States a unique case? a comparative study of nine OECD countries. Review of Economic Dynamics 5: 408-42. Crossref

10. Czernich, N., Falck, O., Kretschmer, T. and Woessmann, L. (2011), "Broadband infrastructure and economic growth*", The Economic Journal, John Wiley \& Sons, Vol. 121 No. 552, pp. 505-532

11. Donou-Adonsou, F. and Lim, S. (2018), "On the importance of Chinese investment in Africa", Review of Development Finance, Vol. 8 No. 1, pp. 63-73.

12. Erumban, A.A. and Das, D.K. (2016)Information and communication technology and economic growth in India, Telecommunications Policy, Elsevier, Vol. 40 No. 5, pp. 412-431 Crossref

13. Evangelista, R., Guerrieri, P. and Meliciani, V. (2014), “The economic impact of digital technologies in Europe", Economics of Innovation and New Technology, Routledge, Vol. 23 No. 8, pp. 802-824.

14. Freeman, Christopher, and Luc Soete. (1997). The Economics of Industrial Innovation. Cambridge: MIT Press.

15. Ghosh, S. (2017), "Broadband penetration and economic growth: do policies matter?", Telematics and Informatics, Vol. 34 No. 5, pp. 676-693. Crossref

16. Henry, O. and Stephen, O. (2010), "Information and communication technologies adoption in SMEs: a literature review", Journal of Chinese Entrepreneurship, Emerald Group Publishing, Vol. 2 No. 1, pp. 93-104. 
17. International Telecommunication Union (2018), Measuring the Information Society Report 2018, ITU Publications, Geneva, Vol. 1.

18. Ishida, Hazuki. (2015). The effect of ICT development on economic growth and energy consumption in Japan. Telematics and Informatics 32: 79-88. Crossref

19. Khan, H., Khan, U., Jiang, L.J. and Khan, M.A. (2020), "Impact of infrastructure on economic growth in South Asia: evidence from pooled mean group estimation", The Electricity Journal, Vol. 33 No. 5, p. 106735.

20. Kumar, R.R., Stauvermann, P.J. and Samitas, A. (2016), “The effects of ICT on output per worker: a study of the Chinese economy", Telecommunications Policy, Vol. 40 No. 2, pp. 102-115. Crossref

21. Kurniawati, M.A. (2017), "Causal interaction between FDI, capital formation, trade and economic growth: evidence from dynamic panel analysis Kurniawati", Journal of Business and Policy Research, Vol. 12 No. 1, pp. $72-87$.

22. Kurniawati, M.A. (2020), "The role of ICT infrastructure, innovation and globalization on economic growth in OECD countries, 1996-2017”, Journal of Science and Technology Policy Management, Vol. 11 No. 2

23. Lee, S.-O., Hong, A. and Hwang, J. (2017), "ICT diffusion as a determinant of human progress", Information Technology for Development, Routledge, Vol. 23 No. 4, pp. 687-705. Crossref

24. Maneejuk, P. and Yamaka, W. (2020), "An analysis of the impacts of telecommunications technology and innovation on economic growth", Telecommunications Policy, Vol. 44 No. 10, 102038.

25. Maneejuk, P. and Yamaka, W. (2020), "An analysis of the impacts of telecommunications technology and innovation on economic growth", Telecommunications Policy, Vol. 44 No. 10, 102038.

26. Millicom and the GSMA. (2018). Driving digital inclusion in Rwanda through the Mobile Internet Skills Training Toolkit. Online at https://www.gsma.com/mobilefordevelopment/country/rwanda/millicom-gsma-drivingdigitalinclusion-rwanda-mobile-internet-skills-training-toolkit/, accessed 20/4/19

27. Muhammad, B. and Khan, S. (2019), "Effect of bilateral FDI, energy consumption, $\mathrm{CO} 2$ emission and capital on the economic growth of Asia countries", Energy Reports, Vol. 5, pp. 1305-1315. Crossref

28. Myovella, G., Karacuka, M. and Haucap, J. (2020), "Digitalization and economic growth: a comparative analysis of Sub-Saharan Africa and OECD economies", Telecommunications Policy, Vol. 44 No. 2, 101856.

29. Nair, M., Pradhan, R.P. and Arvin, M.B. (2020), "Endogenous dynamics between $\mathrm{R} \& D$, ICT and economic growth: empirical evidence from the OECD countries", Technology in Society, Vol. 62, 101315.

30. Raheem, I.D., Tiwari, A.K. and Balsalobre-Lorente, D. (2020), "The role of ICT and financial development in $\mathrm{CO} 2$ emissions and economic growth", Environmental Science and Pollution Research, Vol. 27 No. 2, pp. 1912-1922. Crossref

31. Roller, L.H. and Waverman, L. (2001), "Telecommunications infrastructure and economic development: a simultaneous approach", American Economic Review, Vol. 91 No. 4, pp. 909-923.

32. Rwanda Economic Update (2020). Accelerating Digital Transformation in Rwanda. https://documents1.worldbank.org/curated/en/912581580156139783/pdf/RwandaEconomic-Update-Accelerating-Digital-Transformation-in-Rwanda.pdf

33. Salahuddin, M. and Alam, K. (2015), "Internet usage, electricity consumption and economic growth in Australia: a time series evidence", Telematics and Informatics, Vol. 32 No. 4, pp. 862-878. Crossref 
34. Salahuddin, M. and Gow, J. (2016), "The effects of Internet usage, financial development and trade openness on economic growth in South Africa: a time series analysis", Telematics and Informatics, Vol. 33 No. 4, pp. 1141-1154.

35. Solarin, S.A. (2020), "The effects of shale oil production, capital and labor on economic growth in the United States: a maximum likelihood analysis of the resource curse hypothesis", Resources Policy, Vol. 68, 101799.

36. Solomon, E.M. and van Klyton, A. (2020), "The impact of digital technology usage on economic growth in Africa", Utilities Policy, Vol. 67, 101104. Crossref

37. Stock, T. and Seliger, G. (2016), "Opportunities of sustainable manufacturing in industry 4.0", Procedia CIRP, Vol. 40, pp. 536-541.

38. van, A.H.H., Gupta, A. and Erumban (2011), Measuring the Contribution of ICT to Economic Growth, Fundaci'on Telef'onica, Madrid.

39. World Bank (2019). A Single Digital Market for East Africa. Online at See: http://documents.worldbank.org/curated/ en/809911557382027900/A-Single-DigitalMarket-for-East-Africa-Presenting-Vision-Strategic-FrameworkImplementationRoadmap-and-Impact-Assessment

40. Yakunina, R.P. and Bychkov, G.A. (2015), "Correlation analysis of the components of the human development index across countries", Procedia Economics and Finance, Vol. 24, pp. 766-771. Crossref

41. Zhang, J. and Danish (2019), "The dynamic linkage between information and communication technology, human development index, and economic growth: evidence from Asian economies", Environmental Science and Pollution Research, Vol. 26 No. 26, pp. 26982-26990. Crossref 